UDC 811.111-161.3-581

DOI https://doi.org/10.24919/2663-6042.15.2021.4

\title{
PECULIARITIES OF BUSINESS CORRESPONDENS IN CHINESE, ENGLISH, AND UKRAINIAN: FORMS OF POLITENESS
}

\author{
Bilyanina V. I. \\ National Academy of Security Service of Ukraine
}

\begin{abstract}
The article is devoted to the forms of expressing a polite tone in international business correspondence. Emphasis is placed on three languages: English, Chinese and Ukrainian, as the main languages used in Sino-Ukrainian business correspondence. The study takes into consideration the cultural characteristics, as well as the native language of the author of the business letter. The author analyzes factual material in the amount of 150 business letters (50 from each language) and classifies common and different elements to express politeness. The article highlights the general aspects of politeness of business correspondence (the presence of polite forms of address at the beginning of the business letter and standardized clichés - at the end); defines means specific to each language to give a business letter a polite tone: temporal forms and prepositions for the English language; polite forms of nouns and idioms for the Chinese language; pronouns and adjectives for the Ukrainian language. The article groups the peculiarities of giving politeness to business correspondence common to the studied languages: polite forms of pronouns, lexical and grammatical clichéd formulas, use of interrogative forms, use of verbs and verbal phrases. The study makes an accent on the ability of the Chinese language to use regular idiomatic phrases and four-syllable word forms, noun and verb forms of politeness instead of English and Ukrainian, which, in turn, showed their structural flexibility and variability. The study stresses out grammatical form as one of the main means of conveying a polite tone of a message with a negative connotation, refusal, or expression of dissatisfaction, being a characteristic of English and Ukrainian business correspondence. The author identifies the linguistic and cultural reasons for the research results (belonging to different language families, differences in the language pictures of the world and historically formed idea of "politeness" (the concept of "politeness"), which is different in Eastern and Western cultures).
\end{abstract}

Key words: business correspondence, polite tone, polite expressions, cliché word formulas.

Біляніна В. І. Особливості англійського, китайського та украйнського ділового листування: форми ввічливості. Стаття присвячена формам висловлення ввічливого тону в міжнародному діловому листуванні. Акцент зроблено на трьох мовах: англійській, китайській та украӥнській як основних мовах, якими послуговуються в китайсько-украӥнському діловому листуванні. Актуалізовано культурні особливості, а також рідну мову автора ділового листа. Проаналізовано фактичний матеріал обсягом 150 бізнес листів (по 50 з кожної мови) та систематизовано спільні й відмінні елементи вираження ввічливості.

У дослідженні висвітлено загальні аспекти ввічливості ділової кореспонденції (наявність ввічливих форм звернення на початку ділового листа та стандартизованих клішованих фраз наприкінці); визначено засоби, характерні для кожної мови з надання діловому листу ввічливого тону: часові форми та прийменники - для англійської мови; ввічливі форми іменників та ідіоми - для китайської мови; займенники та прикметники - для украӥнської мови. Виокремлено спільні для досліджуваних мов особливості надання діловому листуванню ввічливого тону: ввічливі форми займенників, лексико-граматичні клішовані формули, використання запитальних форм, уживання дієслів та віддієслівних зворотів. Наголошено на превалюванні в китайській мові можливостей використання сталих ідіоматичних фраз та чотирискладових словоформ, іменникових та дієслівних форм ввічливості порівняно з англійською та украӥнською мовами, які, своєю чергою, виявили свою структурну гнучкість та варіативність. Виділено граматичну форму як один з основних засобів передачі ввічливого тону повідомленням з негативним відтінком, відмовою або вираженням незадоволення, характерних для англомовного та украӥнськомовного ділового листування. Окреслено мовно-культурні причини отриманих результатів (належність до різних мовних сімей, відмінності в мовних картинах світу та історично сформованих поняттях «ввічливості» (конщепту «ввічливості») щзодо представників східної та західної культур).

Ключові слова: ділове листування, ввічливий тон, ввічливі вирази, формули слів-кліше.

Defining the problem and argumentation of the topicality of the consideration. China and Ukraine have been recently increasing the number of business contacts in different spheres. Making agreement requires properly organized business correspondence. Numerous studies show that there is a difference, explained mainly by the cultural diversity, in the way of conducting business correspondence. This made us interested in exploring and comparing one of the most distinguished aspects of mailing - forms and ways to express politeness in the three languages mainly used in business correspondence between China and Ukraine.

Analysis of recent research and publications. The question of business correspondence has been explored by many scientists all over the world. According to their main points, researches may be combined into such groups as: business writings' diversity according to the sales genre (D. Boraks [2]; Dan Wu 
and Hui Wu [6]; Zhu Yunxia [5] etc.); business writings' diversity according to the native language of the author (David D. Qian [3]; Lorrita N. T. Yeung [4]); business writings' diversity according to the grammar and lexical side of it (Ying Huaxing [7]; Zu Xuebao [8] etc.). Most of them are concentrated on the English or Chinese languages but there is none making a comparative analysis of the Chinese, English, and Ukrainian language forms of politeness.

Setting the goals and tasks of the article. The goal of our research is to figure out peculiarities of polite form expression that is normal for the Chinese, English, and Ukrainian business languages.

The goal can be achieved with the help of the following steps:

1. Exploring general features of business correspondence in the three (Chinese, English, and Ukrainian) cultures.

2. Emphasizing the role of 'polite expressions' in all the explored languages.

3. Figuring out the most common ways of politeness in the Chinese, English, and Ukrainian languages.

The outline of the main research material.

1. Exploring general features of business correspondenceinthethree (Chinese, English, and Ukrainian) cultures.

Our research is based on the analysis of business correspondence in the amount of 150 copies (50 examples per each language). The explored papers confirmed and supplemented the results mentioned in the studies of
Ying Huaxing [7] and Zu Xuebao [8] and showed certain features that are common for all the three languages:

- Usage of a great number of professional terms and first letters as an abbreviation form for the terms of the sphere $[7 ; 8]$.

- A big role of prepositions [7; 8].

- Usage of polite language forms [7; 8].

- Clearness and accurateness of the form and content.

- Usage of Present Simple in most of the cases.

- Omission of direct denials.

- Usage of polite forms (including words and sentence structure) to reduce unsatisfaction.

It may testify to the unification of business correspondence forms as a genre. It should be noted that only native language mailing was explored and the achieved results do not reflect self-modification of letters as a result of translation.

2. Emphasizing the role of 'polite expressions' in all the explored languages.

The examination of the latest research shows that a polite tone is essential for business correspondence. It is a part of a letter that cannot be omitted; otherwise it may lead to the fact that the deal will not be closed. The findings of our research are shown in the Table 1.

It became clear that even though China is considered to be the most 'reputation making' culture (给面子的) $[6,887]$ by mastering polite forms (word-combinations and state formulas), English and Ukrainian languages give much more possibilities to express polite tone of

Comparative analysis of the expression of polite tone in English,

Table 1 Chinese, and Ukrainian business correspondence

\begin{tabular}{|c|c|c|c|}
\hline & English & Chinese & Ukrainian \\
\hline $\begin{array}{l}\text { Polite forms/words/word } \\
\text { combinations to express } \\
\text { polite tone at the beginning } \\
\text { of the letter }\end{array}$ & $\begin{array}{c}\text { Mr./Mr. } \\
\text { Dear Sirs/Dear Sir } \\
\text { Dear Madam/Dear Mrs. }\end{array}$ & $\begin{array}{l}\text { 先生 } \\
\text { 小姐 } \\
\text { 女士 } \\
\text { 总经理 } \\
\text { 经理 } \\
\text { 雅教 } \\
\text { 專书 } \\
\text { 尊敬的 } \\
\text { 尊重的 }\end{array}$ & $\begin{array}{c}\text { Пан/Пані } \\
\text { Шановний/Шановна } \\
\text { Вельмишановний// } \\
\text { Вельмишановна }\end{array}$ \\
\hline $\begin{array}{l}\text { Words / word combinations } \\
\text { used to express polite tone in } \\
\text { the main body of the letter }\end{array}$ & $\begin{array}{l}\text { Thank you } \\
\text { Please } \\
\text { Look forward to } \\
\text { Hope } \\
\text { Think } \\
\text { Wonder }\end{array}$ & $\begin{array}{c}\text { 贵公司 } \\
\text { 谢谢您…的来信 } \\
\text { 近来生意可好效益颇高 } \\
\text { 久仰大名 } \\
\text { 惠书敬悉，不胜感激 } \\
\text { 拜托之事，承望协助解决 } \\
\text { 为盼 } \\
\text { 请您联系我 } \\
\text { 希望我们能够达成合作 } \\
\text { 感谢您抽空洽谈 }\end{array}$ & $\begin{array}{c}\text { Просимо Вас } \\
\text { Ви } \\
\text { Впевнений, що } \\
\text { (in case of complaining } \\
\text { or unsatisfaction) }\end{array}$ \\
\hline $\begin{array}{l}\text { Words / word combinations } \\
\text { used to express polite tone at } \\
\text { the end of the letter }\end{array}$ & $\begin{array}{c}\text { Yours faithfully / Faithfully } \\
\text { yours } \\
\text { Sincerely } \\
\text { Cordially } \\
\text { Respectfully } \\
\text { Regards } \\
\end{array}$ & $\begin{array}{l}\text { 敬祝 } \\
\text { 顺颂 } \\
\text { 恭祝 } \\
\text { 生意兴隆 } \\
\text { 静候佳音 }\end{array}$ & $\begin{array}{c}3 \text { повагою } \\
3 \text { найкращими побажан- } \\
\text { нями }\end{array}$ \\
\hline $\begin{array}{l}\text { Tense used to express polite } \\
\text { tone }\end{array}$ & $\begin{array}{l}\text { Present Simple/Continuous } \\
\text { "Could/Would/Should" } \\
\text { sentences }\end{array}$ & 问候语 & Теперішній час \\
\hline
\end{tabular}


the letter (by means of grammar). Research shows that $80 \%$ of polite tone in the Chinese language business correspondence is created by word combinations. Most of them have the same structure as traditional idioms (four words combination) used as a cliché.

For example: 静候佳音 (look forward to hearing good news from you): Adjective + Verb + Adjective + Noun; 生意兴隆 (wish your business booming): Noun + Verb or if to define in a traditional word meaning: Verb + Noun + Verb + Adjective.

Such structure is typical for the old Chinese 成语 (idiom) and is used mainly at the end of the letter. If we take into consideration the lexical side of the letter, the Chinese language also provides more variety of polite lexis $(59 \%)$ used in the main body of the letter than English $(27,4 \%)$ and Ukrainian $(13,6 \%)$ languages. It does not have tense changes and sticks to a wide use of an old traditional sentence structure, where one- two-syllable words prevail over modern Chinese two-, threeand sometimes four-syllable words. But it was found out that this deficiency was substituted by a number of two-syllable verbs to deliver polite effect.

For example: 谢谢(thank you), 感激 (feel grateful), 拜托 (polite form for 'please'), 承望 (polite form for 'look forward to'), 感谢 (extremely grateful).

According to the research, we stand that English and Ukrainian languages give more variety of sentence modification due to grammar and differences of tenses that can deliver polite tone than that of the Chinese language.

For example: We're writing to you in the hope that we can open up business relations with your firm $[6,886]$.

Here Present Continuous is used to make the sentence sound more polite. The same sentence in Chinese would sound:

\section{希望能够与贵公司建立业务关系。}

In this case polite tone is conveyed by the address word (Noun '贵'). A Ukrainian variant of the sentence may be the following:

Цим листом маємо намір з усією впевненістю засвідчити наше щире прагнення започаткувати ділові стосунки з Вашою фірмою.

Here polite tone is expressed by polite address word (Pronoun 'Baw') and adjective 'mupe'.

3. Figuring out the most common ways of politeness in the Chinese, English, and Ukrainian languages.

Even though there are some common aspects of business letter wring, there are still some specific language peculiarities. According to the research of Dan Wu and Hui Wu [6, 884-886], it is usual for the English business mailing to use:

- conjunction of opposition to express consent;

- prepositional phrases;

- euphemisms;

- negative sentences to express polite flexibility;

- questions to make suggestions or requisitions but in a tactful manner;

- loan words, such as adverbs composed of 'here', 'there', 'after', 'in', 'from', and other prepositions;

- verbs 'hope', 'think', 'wonder', 'want' etc. to make the letter more polite.

As for the Chinese business writing peculiarities, according to the research made by Zhu Yunxia [5], the structure and the language / style of the latter depends on one of the three genres, that comprise ‘下行' or 'from superior to subordinate', '上行' or 'from subordinate to superior' and '平行' or 'equals writing to each other' [5]. It requires changes in both structure and lexis, still, such polite phrases as: 尊敬的：尊重的： 贵公司：“X先生”will remain unchanged.

According to "The Point" [1], it is typical for the Ukrainian language business correspondence to use:

- structures 'згідно з' instead of 'згідно чого';

- structures 'відповідно до' instead of ' $y$ відповідності до';

- structures 'порівняно з' instead of 'у порівнянні з';

- usage of preposition ' 3 ' instead of ' $n o$ ';

- usage of endings ' $a x$ '/ ' $g x$ ' instead of ' $a \mu$ '/ ' $я$ '.

Common for the three languages is the necessary use of polite forms at the beginning ('尊敬的? 尊重的'; 'Dear', 'Mr. / Ms.'; 'Пан / Пані', 'Шановний / Шановна', 'Вельмиповажний / Вельмиповажна') and the end of the letter ('Sincerely yours', 'Best regards'; '3 повагою', '3 найкращиими побажаннями'), but the way of conveying the polite tone in the letter body depends on the language.

For example, English correspondence uses conjunctions tomake the tonemore peaceful and euphemisticinsentences, especially to convey negative news $[6,884-885]$. It is also normal for the English business correspondence to use prepositional phrases to make sentences catchier, and to increase the degree of formality and politeness.

It is common for the Chinese business correspondence to use long, verb-oriented complicated sentences. Even though, the polite tone is expressed by address nouns, idioms and polite verbs. The research shows that the number of polite verbs is 32\% bigger than in in English and $46 \%$ bigger than in the Ukrainian language.

Talking about the Ukrainian business correspondence, it should be mentioned that the polite tone of the letter can be conveyed with the help of addressing forms that can express the rate of our respect to the reader. Avoiding direct 'no', it is a must to express regrets and sorrow of declining the proposition; it can be done with the help of adjectives that are able to preserve the polite tone of the text [1].

Obtained results can be explained as follows: first of all, all three languages belong to different language families and they do have structural peculiarities developed with the time; secondly, English and Ukrainian languages represent Western culture, while Chinese language represents Eastern. Western culture is often considered to be more 'open' than the Eastern one (not only because China itself was closed to the entire world for a long time, but also because it has different moral norms and standards of behavior). As well as Chinese culture was based on the Buddhist's norms of world perception and Confucian norms of politeness and respect, it is normal for them to 'minimize' themselves by giving addressee lots of greetings and respect. It also explains the minimized forms of sentence structures that have their roots in the Buddhists' ideas of minimalism and simplicity. As for the European countries, our world perception is more self-oriented and does not have such restrictions.

Conclusions and directions for further research in this area. Comparative analysis of the ways to convey the polite tone in three languages (English, Chinese, 
and Ukrainian) revealed several peculiarities of business letter writing. It was found that the three languages use their own ways to express a polite tone in business correspondence. It was proved that English business letters create the polite tone by means of address words at the beginning of the letter; conjunctions, prepositional phrases, loan words, verbs, the Present Continuous Tense, and an interrogative sentence in the main body of the letter and polite word combinations at the end of it.

It was confirmed that Chinese business correspondence gives the letter a polite tone with the help of polite address words at the beginning of the letter; polite words (mainly verbs) and word combinations / set phrases (idioms) in the main body of the letter and idiomatic phrases at the end of it.
It was shown that Ukrainian business communication conveys a polite tone by means of polite address words at the beginning of the letter; pronouns, adjectives, sentence structures (avoiding direct rejections, using question forms) in the main body of the letter and polite phrases at the end of it.

Even though there is a difference in using polite forms in business correspondence of English-speaking countries, China and Ukraine, that have to be taken into the consideration while writing a letter, there are also some common ideas of business letter structure which makes it easier to achieve the desired result.

The article was concentrated on the forms of polite tone expression with no regards to a particular type of the business letter.

\section{BIBLIOGRAPHY}

1. Ділове листування : правила звернення, вибачення, відмови та прощання українською мовою. URL: https://loyer. com.ua/uk/dilove-listuvannya-pravila-zvernennya-vibachennya-vidmovi-ta-proshhannya-ukrayinskoyu-movoyu/ (accessed 21 May 2021).

2. Boraks D. Chinese Business Culture: Doing Business in the Chinese-Speaking World. 2007. URL: http://chinese-school. netfirms.com/doingbusiness.html (accessed 21 May 2021).

3. David D. Qian, Mingwei Pan. Politeness in Business Communication: Investigating English Modal Sequences in Chinese Learners' Letter Writing. RELC Journal. 2019. Vol. 50. Issue 1. P. 20-36. URL: https://journals.sagepub.com/doi/ full/10.1177/0033688217730142 (accessed 21 May 2021).

4. Lorrita N. T. Yeung. Polite requests in English and Chinese business correspondence in Hong Kong. Journal of Pragmatics. 1997. Issue 27. P. 505-522. URL: http://course.sdu.edu.cn/G2S/eWebEditor/uploadfile/20131201161747008.pdf (accessed 21 May 2021).

5. Zhu Yunxia. Business Writing in Mainland China: A Look at the Development of Sales Genres. Intercultural Communication. 2000. Issue 3. URL: https://www.immi.se/intercultural/nr3/zhu.htm (accessed 21 May 2021).

6. 吴慧,吴丹. 国际商务函电中礼貌原则运用研究。 ICEMC． 2016. P. 883-888. URL： file:///C:/Users/38050/ Downloads/25856755.pdf (accessed 21 May 2021).

7. 英华丽萍. 外贸函电用词特点及其翻译常用词汇类别和用法. 2020. URL: http://www.jmkwh.com/p/2020515195253 $7289601216577 / \mathrm{tag} \% \mathrm{E} 5 \% \mathrm{~A} 4 \% 96 \% \mathrm{E} 8 \% \mathrm{~B} 4 \% \mathrm{~B} 8 \% \mathrm{E} 9 \% 80 \% 9 \mathrm{~A}$ (accessed 21 May 2021).

8.祖雪宝.商务英语的翻译特点与原则.公务员之家.URL:https://www.gwyoo.com/lunwen/jylw/swyylw/201603/621928. html (accessed 21 May 2021).

\section{REFERENCES}

1. Dilove lystuvannia: pravyla zvernennia, vybachennia, vidmovy ta proshchannia ukrainskoiu movoiu [Business correspondence: rules of appeal, apology, refusal and farewell in Ukrainian]. Retrieved from: https://loyer.com.ua/uk/dilovelistuvannya-pravila-zvernennya-vibachennya-vidmovi-ta-proshhannya-ukrayinskoyu-movoyu/ (accessed 21 May 2021) [in Ukrainian].

2. Boraks, D. (2007). Chinese Business Culture: Doing Business in the Chinese-Speaking World. Retrieved from: http://chinese-school.netfirms.com/doingbusiness.html (accessed 21 May 2021)

3. David, D. Qian, Mingwei, Pan (2019). Politeness in Business Communication: Investigating English Modal Sequences in Chinese Learners' Letter Writing. RELC Journal, 50 (1), 20-36. Retrieved from: https://journals.sagepub.com/doi/ full/10.1177/0033688217730142 (accessed 21 May 2021)

4. Lorrita, N. T. (1997). Yeung. Polite requests in English and Chinese business correspondence in Hong Kong. Journal of Pragmatics, 27, 505-522. Retrieved from: http://course.sdu.edu.cn/G2S/eWebEditor/uploadfile/20131201161747008.pdf (accessed 21 May 2021)

5. Zhu Yunxia (2000). Business Writing in Mainland China: A Look at the Development of Sales Genres. Intercultural Communication, 3. Retrieved from: https://www.immi.se/intercultural/nr3/zhu.htm (accessed 21 May 2021)

6. Vu Xuej, Vu Dan (2016). Doslidzhennya zastosuvannya pry`ncy`pu vvichly`vosti u mizhnarodnij dilovij korespondenciyi [Research on the Application of Politeness Principle in International Business Correspondence]. ICEMC, 883-888. Retrieved from: file://C:/Users/38050/Downloads/25856755.pdf (accessed 21 May 2021) [in Chinese].

7. Yin Xuajpin (2020). Kharaktrystyka sliv zovnishnoekonomichnoi korespondentsii ta yikh zahalnyi slovnykovyi zapas, pereklad, katehorii ta vykorystannia [The characteristics of foreign trade correspondence terms and their translation common vocabulary categories and usage]. Retrieved from: http://www.jmkwh.com/p/2020515195253_7289_601216577/ tag_\%E5\%A4\%96\%E8\%B4\%B8\%E9\%80\%9A (accessed 21 May 2021) [in Chinese].

8. Zu Syuebao. Osoblyvosti ta pryncypy perekladu dilovoyi anglijskoyi movy [Features and Principles of Business English Translation]. Dim derzhavnyx sluzhbovciv. URL: https://www.gwyoo.com/lunwen/jylw/swyylw/201603/621928.html (accessed 21 May 2021) [in Chinese]. 